\title{
Global Citizenship and Cosmopolitan Governance in the Legal Philosophy of K.C.F. Krause
}

\author{
Claus Dierksmeier
}

\begin{abstract}
In the early 1800 s, K.C.F. Krause penned a legal philosophy of an unreservedly cosmopolitan bent. In bold strokes, Krause transcended the methodological nationalism of the philosophy of his era, drafting constitutional designs for supranational institutions on the European as well as on the global level. Finding that human rights have their ultimate foundation in the freedom of each and all persons, Krause demanded these rights to be universalized strictly in terms of both their protection and promotion. He called therefore for reparations for colonial injustices, for the empowerment of hitherto marginalized or disenfranchised groups just as much as, going forward, a genuine respect for the rights and interests of future generations. This article tries to reconstruct core arguments of Krause's cosmopolitan position so as to elucidate their current relevance and systematic validity.
\end{abstract}

Keywords: cosmopolitanism - democracy - European union - German Idealism universal freedom - world citizenship

\section{Introduction}

Around the year 1800, German philosophy saw its heyday. In Jena and Weimar especially, the later icons of German Idealism, Classicism, and the Romantic movement Fichte, Schelling, and Hegel, Goethe and Schiller as well as the Schlegel brothers, to name but a few - vied for public attention producing, in fast succession, a vast array of impressively innovative works. Said productivity extended not in the least to the field of legal philosophy, where numerous scholars of the day tried to make a name for themselves as successors of Kant by attempting to reconcile the coercive nature of laws with the idea that inspired the post-Kantian era as a whole: freedom. Among them was a young academic whose name, albeit of certain renown still in Iberophone countries, was all but forgotten in his home country Germany and never really took hold in the Englishspeaking world: Karl Christian Friedrich Krause (1781-1832). ${ }^{1}$

Alongside his better remembered contemporaries, Krause stands out because of the immensely progressive and markedly cosmopolitan nature of his works. At a time when the prevailing tone in philosophical tomes was formed by jarring chords of a nationalistcum-sexist chauvinism, Krause opted for an inclusive philosophy of freedom, integra-

\footnotetext{
${ }^{1}$ For a comprehensive contextualization of Krause's philosophy see the extensive studies by Ureña, K. C. F. Krause: Philosoph, Freimaurer, Weltbürger: Eine Biographie, 1991, and, Philosophie und Gesellschaftliche Praxis: Wirkungen der Philosophie K. C. F. Krauses in Deutschland, 1833-1881, 2001.
} 
tive of difference and diversity, pleading for the elimination of any kind of religious, sexual, and racial discrimination. Directed to humanity in its entirety, his philosophy considered - at the outset of the $19^{\text {th }}$ century - issues such as the empowerment of women as well as the legal representation of unborn children, minors, the disabled, and future generations. Moreover, promoting global governance structures for the peaceful resolution of international conflicts, Krause devised various institutional schemes for federalist regional (i.e. European) institutions and global governance, and, last but not least, his treatises are replete with reflections on the importance of sustainable development, the need for solidarity in subsidiarity, and the like.

Such - around 1800 highly unusual - postulates were not merely prophecies of a consciousness in mystical communion with the future, or so I shall argue. They can rather be derived consistently from the fundamentals of Krause's philosophy. Krause aspired to a methodologically consistent implementation of the Kantian project of a self-reflective as well as self-critical philosophy of freedom: dialogically, phenomenologically, and discursively. That is to say, while Kant had drawn on the critical self-reflexivity of the idea of freedom for determining its normative content, Krause appropriated that selfsame model also for the method of philosophy. Krause sought to involve all persons in the generation of the very rules under which they were to live; wherever possible in a direct and participatory manner, and wherever this was (still) impossible, at least in an indirect and representative way. From this approach, Krause developed a highly inclusive cosmopolitan ethics whose potential has up to now in no way been exhausted.

In what follows, I am providing an introduction to Krause's supranational philosophy of law which, beyond a doxographic account of its tenets, aims at an argumentative reconstruction of how it forms a coherent architecture erected above the foundations of a self-critical notion of freedom. In a first step, I expound Krause's take on the struggle of post-Kantian philosophers to reconcile freedom and coercion in legal philosophy (II.). Next, I showcase how Krause's idea of a freedom-oriented law provides a philosophical legitimation as well as limitation of democratic government (III.). Then, I flesh out Krause's theory of supranational law on both the European (IV.) and global level (V.), before concluding (VI.).

\section{Individual Freedom and Legal Coercion}

Legal coercion, through limiting individual liberty, is of particular interest to any and all legal philosophers premised on the idea of freedom. ${ }^{2}$ To justify such coercion, a liberal philosopher cannot, like e.g. utilitarians, simply refer back to the benefits which legal coercion may provide. Any and all reasons for coercion, which are not themselves related to the idea of freedom, can - and, at long last, certainly will - be rejected in the name of freedom. Moral or religious justifications are likewise problematic. The validity of subjecting to legal coercion even those who do not share in those normative horizons cannot thus be derived. That is to say, although morality, religion, and a utility-conscious prudence provide sound secondary reasons to behave lawfully, they do not

\footnotetext{
${ }^{2}$ See Köhler, Recht und Gerechtigkeit: Grundzüge einer Rechtsphilosophie der verwirklichten Freiheit, 2017, $11 \mathrm{ff}$.
} 
capture what needs to be primarily identified here, i.e. a rationale for coercion that adheres to the principle of freedom itself. ${ }^{3}$

The attempt merely to define coercion as the double negation of freedom - in the words of Kant as "a hindering of a hindrance of freedom" - also has its shortcomings, as Kant himself made clear: The right to freedom can ultimately not be explained by the authorization to coerce; inversely, any authorization to coerce always must depend on the rights it is to protect. Thus, the recourse to the concept of coercion leads immediately back to the question what defines legitimate freedom. Whoever does not want to confound facts with norms nor equate the freedom that ought to exist with the freedom that does, has to indicate first which freedoms are supposed to be defended through legal coercion. Consequently, the question about which freedom everyone has - or ought to have - an inviolable right to must be settled before attempting a definition and justification of coercion. As a result, from the perspective of freedom-oriented philosophy, legal positivism fails in the attempt to define 'right' only in terms of what a state declares to be right. The requisite self-sufficiency of the justification of legal coercion clearly means something entirely different than a self-legitimation of legal facticity through decisionism. ${ }^{5}$

Hence, the German idealists concluded, freedom must limit itself. ${ }^{6}$ Whoever is coerced by me will hardly agree with my coercion if, as a result, only my freedom is secured, while theirs is annihilated. I must rather make it clear that also their freedom is defended. For that reason, not merely my purely private possession of freedom, but rather an interpersonally valid content of freedom, has to serve as the defining criterion. The only principle that can acceptably limit anyone's freedom must be the one that at the same time affirms everyone's freedom. Private freedom thus forever refers beyond itself to the horizon of societal - and, strictly speaking, universal - freedom, without which it is theoretically null and practically void. To legitimate coercion, Krause concluded, the idea of universal freedom, the freedom of each and all, has to become the normative yardstick for the evaluation of any claim to providing a moral foundation of law and its right to coerce, be it on the local, the national, the regional, or the global level.

For Krause, it is clear that such universal freedom, resting in humanity's "reasonable nature," must be regarded - even for the respective persons themselves - as strictly inviolable. Universal "rights for world citizens" (Weltbürgerrechte) are to be proclaimed, which guarantee basic freedoms to all human beings, not based on their particular citizenship, class membership, religious affiliation, gender, or individual attributes, but solely in virtue of their general personhood. About those cosmopolitan rights, Krause writes in 1803, at the age of 21 years: 164.

${ }^{3}$ See Dierksmeier, Qualitative Freedom - Autonomy in Cosmopolitan Responsibility, 2019, 162

${ }^{4}$ Kant, Metaphysik der Sitten (1797), in: Kants Gesammelte Schriften edited by the Königlich PreuBische Akademie der Wissenschaften. First Section, Vol. 6, 203 (231).

${ }^{5}$ See Dierksmeier, Der absolute Grund des Rechts. Karl Christian Friedrich Krause in Auseinandersetzung mit Fichte und Schelling, 2003, 8 ff.

${ }^{6}$ See Dierksmeier, Recht und Freiheit. Karl Christian Friedrich Krauses ,Grundlage des Naturrechts ' im Kontext des Jenaer Idealismus, International Yearbook of German Idealism/Internationales Jahrbuch für Deutschen Idealismus 2 (2004), 309-334. 
"They belong to me not insofar as I am a citizen of this particular region and state, but insofar as I am a citizen of the world. I can thus call them, together with the rights to my body, as the proximate condition of their attainment, my rights as a world-citizen, and call my possession of them my cosmopolitan property; they rank higher than any positive form of coercion and are indelibly etched into the legal constitution of the world [Gesetzbuch der Welt]."

Yet which exactly are these rights, and how are they to be specified, promoted and protected? How are these lofty ideals to be made tangible so as to make a difference in the world of politics and constitutional law? Who has the right to settle such questions, and how? Where there is no world state directed by a democratically organized citizenry, who are the constituents, and which are the institutions that might bring about the theoretical qualification and practical realization of said cosmopolitan rights?

\section{Whose Law? \\ The Legitimation and Limitation of Democratic Government}

Since the idea of freedom demarcates not only the highest content of his philosophy, but serves also as its ultimate methodological principle, Krause has no desire to present his philosophy of freedom as ready-made before the public. He rather aims for the active contribution of the public. If a philosophy of freedom is to be liberating, he holds, freedom's ends and means must harmonize. Philosophy's path, so to speak, has to foreshadow its goal. For that reason, Krause focuses upon dialogical argumentation, comprehensible thought-experiments, and a theory formation - open to falsification designed for the empirical testing of its explanatory power. In short, he focuses upon participatory methods which only much later became widely adopted in academic philosophy. ${ }^{8}$

Practical philosophy, too, is meant to reflect this inclusive spirit and take into consideration the everyday worldviews of the citizens, instead of decreeing its normative principles 'from above.' The voice of the citizens is the equivalent to what in theoretical philosophy is the empirical experiment: a test for the plausibility and integrative potential of the philosophical ideas at issue. The political upshot of these considerations is an endorsement of constitutional democracy as the most suitable means to the end of a government based on and respectful of the freedoms of the citizens. The integration of the people's will into legislation and government may, though, never take place at the cost of the principle of law, warns Krause: "The fact that one or millions are deciding for an action in complete agreement makes it neither just nor unjust". ${ }^{9}$ Democracy must never degenerate into the tyranny of the majority. ${ }^{10}$ Only the systematic mediation of the empirical will of the people with the normative idea of law can legitimately determine the state's activity. Freedom must never be surrendered to the sheer will of either the

\footnotetext{
${ }^{7}$ Krause, Grundlage des Naturrechts, oder philosophischer Grundriss des Ideales des Rechts. Erste Abtheilung, 1803, 28.

${ }^{8}$ For more detailed information about this see Dierksmeier, Der absolute Grund des Rechts, 2003, Chapter IV.

${ }^{9}$ Krause, Vorlesungen über Naturrecht oder Philosophie des Rechts und des Staates, ed. by Mucke, 1892, 228.

${ }^{10}$ Krause, Abriss des Systemes des Rechtes oder des Naturrechts, 1828, 129.
} 
state apparatus or the majority of the population. Citizens owe obedience only to a lawful regime.

\begin{abstract}
"A state can certainly not demand the blind obedience of its citizens, but can demand free obedience, that is, an obedience grounded upon their own recognition of the reasonableness of the laws; otherwise the state would make machines out of its citizens, would itself hinder reason and profane its own vocation (G II 173)."11
\end{abstract}

The universal will is not the same as the will of the majority; it must rather be generated through a legislation orientated around the rule of law. ${ }^{12}$ The legitimate will of the people, that is, does not exist before and outside of the constitutional procedures, but rather emerges from them. ${ }^{13}$ One cannot, as a consequence, divide democratic substance from its constitutional form and play them off against one another. Since procedures and principles require as well as condition each other, only insofar as citizens govern themselves lawfully "are the people themselves the sole administrator of law, sovereign, and autocrat",${ }^{14}$ and only then is there "a community, res publica, in the complete, genuine sense of the term". ${ }^{15}$ Under this strict, often unfulfilled precondition alone one is entitled to say "that what the community establishes as right is right in itself as well". ${ }^{16}$ Where such a legal representation of the will of the people succeeds, Krause prioritizes the idea of the parliamentary democracy over all other extant forms of government. ${ }^{17}$

In order to assure that democracy is subordinated to the law and this, in turn, remains subordinated to the idea of freedom, Krause demands a policy of "absolute publicity" ${ }^{18}$ Legislative "decrees must have disclosure, that is, they must be publicly decided, publicly announced, and accessible to everyone at all hours." 19 Publicity enables and promotes public participation. ${ }^{20}$ It lets individual and collective freedom find within each other a regulative instance so that they together can co-construct and reciprocally optimize the democratic will. Yet this delicate process of open deliberation requires strong and apt democratic institutions whose functioning is best assured over time by properly enshrined constitutional arrangements.

This declaration in favor of a modern constitutional state with a parliamentary democracy is, for Krause, however, in no way the same as a sanctification of the

\footnotetext{
${ }^{11}$ Krause, Grundlage des Naturrechts, oder philosophischer Grundriss des Ideales des Rechts. Zweite Abtheilung, ed. by Mollat, 1890, 173.

${ }^{12}$ Krause, Das System der Rechtsphilosophie - Vorlesungen für Gebildete aus allen Ständen, ed. by Röder, 1874, 523.

${ }^{13}$ Ibid., 522. This distinction between immediate people's sovereignty and lawfully, i.e. institutionally mediated national sovereignty is further developed by Krause's follower, Heinrich Ahrens, Die organische Staatslehre auf philosophisch-anthropologischer Grundlage, 1850, 197.

${ }^{14}$ Krause, Lebenlehre oder Philosophie der Geschichte zur Begründung der Lebenkunstwissenschaft, 1904, 207.

15 Ibid.

${ }^{16}$ Ibid., 211.

${ }^{17}$ Krause, Das System der Rechtsphilosophie - Vorlesungen für Gebildete aus allen Ständen, 1874, 541.

${ }^{18}$ Krause, Der Erdrechtsbund an sich selbst und in seinem Verhältnisse zum Ganzen und zu allen Einzeltheilen des Menschheitlebens, ed. by Mollat, 1893, 109.

${ }^{19}$ Krause, Grundlage des Naturrechts, oder philosophischer Grundriss des Ideales des Rechts. Zweite Abtheilung, 1890, 167.

${ }^{20}$ Krause, Der Erdrechtsbund an sich selbst und in seinem Verhältnisse zum Ganzen und zu allen Einzeltheilen des Menschheitlebens, 1893, 109.
} 
national state per se. ${ }^{21}$ The "people's state [Volksstaat] which one customarily incorrectly only called 'the state", ${ }^{22}$ certainly takes a prominent position in recent history but must never be made absolute. ${ }^{23}$ For, contrary to contemporary tendencies in his era, Krause ascribes no particular significance to the people's ethnicity. For one thing, he explains in detail how legal structures evolve below, above, and alongside of the national sphere. For another, his thought is strictly cosmopolitan and rejects any patriotism devaluing foreign countries. National law, for Krause, does not legitimate itself by itself (as in legal positivism), but does so, to repeat, by its functional contribution to the freedom of all, i.e. by institutionalizing political autonomy so as to "provide" all with their "human rights". ${ }^{24}$ Krause explicitly says that national laws are supposed to be always constituted with regard to the possible "agreement on part of the whole of living humanity." $" 25$ In his footsteps, Latin-American Krausists enshrined cosmopolitan and intergenerational commitment of all national politics into constitutional law. ${ }^{26}$

For Krause, a people is simply the cultural correlate of a legal community. ${ }^{27}$ Only as representatives of humanity are nations authorized to enact and sanction legal norms. Therefore, to him, the idea of a nationalistic liberalism is a non-starter. ${ }^{28}$ Krause rejects Fichte's and Hegel's assumption that the Universal Spirit (Weltgeist) is biased towards certain nations and realizes itself supremely within the German people. Krause counters that "all currently living human beings taken together [must] be considered as representatives of reason itself"' ${ }^{29}$ Krause identifies the universal spirit rather with in humankind as a whole and understands its project to be cosmopolitan in nature. ${ }^{30}$

\footnotetext{
${ }^{21}$ See Rodriguez de Lecea, Der spanische Krausismo als praktische Philosophie, in: Kodalle (ed.), Karl Chrstian Friedrich Krause (1781-1832): Studien zu seiner Philosophie und zum Krausismo, 1985, 202.

${ }^{22}$ Krause, Abriss des Systemes der Philosophie des Rechtes oder des Naturrechts, 1828, 179.

${ }^{23}$ Krause, Lebenlehre oder Philosophie der Geschichte zur Begründung der Lebenkunstwissenschaft, 1904, 203.

${ }^{24}$ Krause, Das System der Rechtsphilosophie - Vorlesungen für Gebildete aus allen Ständen, 1874 , 350 .

${ }^{25}$ Ibid.

${ }^{26}$ The Argentinian constitution of 1853 can in certain essential respects be identified as Krausist, see Barraquerro, Espirit y Práctica de la ley Constitucional argentina, 1878; in that, for instance it is directed towards all of humanity and not only the Argentinian people and that it intends to provide a thoroughly subsidiary and decentralized redistribution of power. See Stoetzer, Raices intelectuales de la Constitución Argentina de 1853, Jahrbuch für Geschichte von Staat, Wirtschaft und Gesellschaft Lateinamerikas 22 (1985), 295-339; as well as Dierksmeier, Harmonischer Liberalismus am Rio de la Plata, Liberal. Vierteljahreshefte für Politik und Kultur 50 (2008), 46-49.

${ }^{27}$ Krause, Lebenlehre oder Philosophie der Geschichte zur Begründung der Lebenkunstwissenschaft, 1904, 206.

${ }^{28}$ Krause, Vorlesungen über Naturrecht oder Philosophie des Rechts und des Staates, 1892, 230; and, Das System der Rechtsphilosophie - Vorlesungen für Gebildete aus allen Ständen, 1874, 352.

${ }^{29}$ Krause, Grundlage des Naturrechts oder philosophischer Grundriss des Ideales des Rechts. Zweite Abtheilung, 1890, $156 \mathrm{f}$.

${ }^{30}$ See Esteban Mateo, El Krausismo en España: Teoria y Circunstancia (1), Historia de la Educación 4 (1985), 97-118.
} 


\section{A Draft for A European Union}

Krause was convinced that for humanity to survive, it must necessarily progress in its ethical development towards ever more social integration well beyond the national level. ${ }^{31}$ Yet, said survival is not at all guaranteed "for it could even be mankind's own misfortune to be extinguished in its prime". ${ }^{32}$ Only concrete historical experience, not abstract speculation can unveil what the future brings. ${ }^{33}$ Human beings may fail in their collective projects just as much as in their individual undertakings. ${ }^{34}$ World history, according to Krause, cannot be speculatively determined.

Krause surmises, however, that the Europe of his day is already on the path towards voluntary cooperation on the supranational level, that is, in a gradual transition from previous periods of national and cultural differentiation to a phase of stronger regional integration based on mutual acknowledgement and reciprocally assured autonomy. ${ }^{35}$ On his view, an important transition is in the making from the anterior quasi-mechanical "system of mere political balance" to a future, more organic legal order. ${ }^{36}$ Most European nations, he argues, do already recognize basic human rights, freedom of religion widely prevails, and technology helps to disseminate ideas across national borders. ${ }^{37}$ What is more, one would find everywhere the seeds of a historically founded common European consciousness. ${ }^{38}$ The epochal step towards a supranational legal order could thus first of all be demanded and expected from Europe. A successful European Union might thereafter be emulated in various regions and serve, eventually, as a model for bringing about a cosmopolitan federation. ${ }^{39}$

But as long as the institutionalization of such a global legal body is still a way off, the rights of individuals and peoples must be promoted through provisional legal systems. ${ }^{40}$ A few states, acting from joint principles, may suffice for a start, according to Krause, ${ }^{41}$ and Europe ought to take the lead. ${ }^{42}$ For example, a European Union could abolish all

\footnotetext{
${ }^{31}$ Krause, Lebenlehre oder Philosophie der Geschichte zur Begründung der Lebenkunstwissenschaft, 1904, 129.

${ }^{32}$ Ibid., 175.

${ }^{33}$ Ibid., 213 note.

${ }^{34}$ Ibid., 160.

${ }^{35}$ Ibid., 376-396.

${ }^{36}$ Krause, Entwurf eines europäischen Staatenbundes als Basis des allgemeinen Friedens und als rechtliches Mittel gegen jeden Angriff wider die innere und äußere Freiheit Europas (1814), $2^{\text {nd }}$ ed. by Reichel, 1920, 9. See MacCauley, Krause's Proposition for a European League of States, The Advocate of Peace 79 (1917), 337-339.

${ }^{37}$ Krause, Lebenlehre oder Philosophie der Geschichte zur Begründung der Lebenkunstwissenschaft, 1904, 425.

${ }^{38}$ Ibid., 422. See Foerster, Europa: Geschichte einer politischen Idee, 1967, 240-243.

${ }^{39}$ Krause, Lebenlehre oder Philosophie der Geschichte zur Begründung der Lebenkunstwissenschaft, 1904, 201; and, Das Urbild der Menschheit, $2^{\text {nd }}$ ed., 1851, 149. It was not by accident that Krause published his Entwurf eines europäischen Staatenbundes in 1814. It contained ideas which Krause had wanted to explain in more detail within his text on Erdrechtsbund, which, however, remained fragmentary, see Der Erdrechtsbund an sich selbst und in seinen Verhältnissen zu allen Einzelheiten des Menschheitlebens, ed. by Mollat, 1893.

${ }^{40}$ Fore more about Krause's "splendid cosmopolitanism" see Fortlage, Genetische Geschichte der Philosophie seit Kant, 1852, 228.

${ }^{41}$ Krause, Das Urbild der Menschheit, $2^{\text {nd }}$ ed., 1851, 142.

${ }^{42}$ Krause, Entwurf eines europäischen Staatenbundes als Basis des allgemeinen Friedens und als rechtliches Mittel gegen jeden Angriff wider die innere und äußere Freiheit Europas, $2^{\text {nd }}$ ed. 1920, 11.
} 
military conflicts on the European continent ${ }^{43}$ and ensure that, at least within its own territorial sphere, the "law of peoples [becomes] increasingly independent of fortune or misfortune, the size of the population, and any arbitrary decision-making". ${ }^{4}$

Krause accordingly drafted a model constitution for a European association of peoples, which all European states should be able to join. The operative idea behind this constitution is that it commits the would-be member states to international law alone. All further purposes, such as the pursuit of free movement across borders, trade and common defense, were to be subordinate to the prime objective: the maintenance of international law. ${ }^{45}$ In particular, the internal affairs of the member states, remaining sovereign within their own legal systems, ${ }^{46}$ should remain unaffected:

\begin{abstract}
"May the Catholic version of the Christian religion be the religion in one state, and the Protestant one reign in the next, or a non-Christian religion in another; may one state have a monarchical constitution, the other a republican or aristocratic, secular or hierarchical constitution: all these states may unite in the confederation, if only those of their features which are contrary to the essence of the confederation, or which cannot attain the general consent of the united states, are not transferred to the confederation itself; if only the peoples, in so far as they form the confederation, keep themselves purely in the field of law." ${ }^{47}$
\end{abstract}

An "organic federal state," which Krause prefers to a crystallization of nations around a "prepotent central state," is to be the eventual outcome. ${ }^{48}$ As a supranational legal federation without independent legal authority, this European confederation of states must rely on the nation states for the protection and realization of human rights. Consequently, the adjustments Krause demands from potential member states are very moderate: peaceful interstate cooperation, mutual recognition of the respective territories, general hospitality as well as the cooperative use of common goods and transport routes. $^{49}$

All member states obtain, due to the equality of all participating peoples as legal entities, equal vote and equal rights in the federation. ${ }^{50}$ The federation grants all states free accession (neither coercion to join nor, without reason, refusal of membership) and free withdrawal (no coercion to stay, no coercion to leave, unless by decision of the international court), etc. ${ }^{51}$ To specify the content of the alliance in detail, the federation proceeds in the following manner: The member states send representatives into a "permanent federal council," where they then decide in equal parts - that is, without a dominating president or the like - as well as unanimously on the federation's legislation, which thereafter a government consisting of the regents of the member states is to implement. ${ }^{52}$ If unanimity cannot be achieved, the objection of individual states usually

${ }^{43}$ Krause, System der Sittenlehre, ed. by Hohlfeld and Wünsche, 1888, 318.

${ }^{44}$ Krause, Entwurf eines europäischen Staatenbundes als Basis des allgemeinen Friedens und als rechtliches Mittel gegen jeden Angriff wider die innere und äußere Freiheit Europas, $2^{\text {nd }}$ ed. 1920, 13.

45 Ibid., 15.

${ }^{46}$ Ibid., 13.

${ }^{47}$ Ibid., 17.

${ }^{48}$ Ibid., 14.

${ }^{49}$ Ibid., 22.

${ }^{50}$ Ibid., 12; and Krause, Das Urbild der Menschheit, 1851, 143.

${ }^{51}$ Krause, Entwurf eines europäischen Staatenbundes als Basis des allgemeinen Friedens und als rechtliches Mittel gegen jeden Angriff wider die innere und äußere Freiheit Europas, $2^{\text {nd }}$ ed. 1920, $22 \mathrm{f}$.

${ }^{52}$ Ibid., 26. 
results in a veto, but in the case of issues of universal relevance to the alliance, an objecting state must submit to the others - or withdraw from the confederation altogether. ${ }^{53}$

In a similar fashion, the alliance settles disputes among alliance states or between external states and the confederation or one of its members. All of these are to be adjudicated by the federation's court of nations. Its decision is binding - without the possibility of appeal. ${ }^{54}$ The court "cannot impose penalties, but [will] present to the wrongdoing state the points it must abide by if it wants to remain a member of the federation." ${ }^{, 5}$ The internal bond of the alliance is complemented by an external one: all matters of international law are now common affairs of the members. "War and peace," in particular, are becoming the concern of the entire confederation, ${ }^{56}$ which thus grows with each accession to an ever more powerful defense alliance. The confederation, at the same time, never acts as an aggressor and makes its internal commitment to international law known externally. By declaring itself saturated regarding territorial claims, the federation can credibly act both passively (as a non-aggressor) and actively (as a mediator and arbitrator) for peace and international law. ${ }^{57}$

\section{Towards Global Governance}

Much as this European union could do, in the eyes of Krause, for the advancement of international law and the promotion of human rights across the globe, the world's citizens can attain absolutely secure rights and perpetual peace only through a global league of nations ${ }^{58}$ For as long as there exists no legal institution spanning the planet, every country can, in cases of conflict, insist upon its right to self-defense. But, where all states act as a judge in their own affairs, arms races and spiraling violence are the consequence..$^{59}$ Krause entertains the hope that, upon realizing this, the world's citizens will sooner or later come together so as to

\footnotetext{
"legally determine the relations of peoples as the whole of mankind and establish a higher organism of law, to which the peoples will relate themselves in the same way that every individual human being relates to his own people". ${ }^{60}$
}

The requisite delegation of state sovereignty rights to higher regional and global unities poses no unsurmountable obstacle to his legal theory, as Krause sees the nation state from the outset as just one - but in no way the only - form for institutionalizing the

\footnotetext{
${ }^{53}$ Ibid., 27.

${ }^{54}$ Ibid., 24.

55 Ibid., 25.

${ }^{56}$ Ibid., 24.

57 Ibid., 29.

${ }^{58}$ See Valentin, Geschichte des Völkerbundgedankens in Deutschland: Ein geistesgeschichtlicher Versuch, 1920, 48 f.; Hetzel, Die Humanisierung des Krieges ihrer culturgeschichtlichen Entwicklung, 1889, 58 und 157; MacCauley, Krause's League for Human Right and Thereby World Peace, 1917,

${ }^{59}$ Krause, Das System der Rechtsphilosophie - Vorlesungen für Gebildete aus allen Ständen, 1874,

${ }^{60}$ Krause, Das Urbild der Menschheit, 1851, 60.
} 458. 500. 
rights of freedom. ${ }^{61}$ Laws, when understood as by Krause as congealed forms of arranging the relations of humans according to the principle of their common freedom, are not beholden to ethnic lineages but should track the lines of real contact and interaction. As a result, in a world where communication and commerce become global, so must the laws that coordinate human freedom in these globalized arenas. Cosmopolitan governance ought to ensue globalization.

Krause's idea of a genuine right is that it imposes a duty upon everyone to assure that it is realized irrespective of contingent circumstances. In just the same way as one avails oneself of one's own human rights, one must help others to realize theirs, regardless of how far away (spatially or temporally) they live, or whether they might at all reciprocate. The disenfranchised of his time (e.g. the victims of colonial injustice) were thus as much of concern for Krause's legal philosophy as the members of future generations. ${ }^{62}$ The fact that in Krause's theory each global citizen is to contribute to the acquisition, protection, and preservation of the rights of every other does not impose, though, undue burdens on the individuals to right all wrongs of the world at once. Notwithstanding, everyone ought to do their part so as to put the world eventually in such a state wherein "every citizen of the planet, wherever he may be heading, is granted his germane personal rights", ${ }^{63}$ and that means that systematic efforts towards an ever stronger institutionalization and implementation of a just system of global governance are indeed a normative obligation on the part of the world citizenry.

The legal world order of Krause's aspirations would bring with it also, it must be highlighted, certain transformations of existing property rights ${ }^{64}$ and modifications of earlier (local, national, and regional) legal systems. ${ }^{65}$ Should a "state of mankind [Menschheitsstaat $]$ on this earth" 66 ever arise, one has to reckon with a redistribution of certain legal positions, which in the light of that new alliance appear in need of reform. ${ }^{67}$ Since the earth is, according to Krause, "the original external property of the entire whole of mankind"68 and fundamentally belongs to "all and everyone," for him this reshuffling of properties is rather unproblematic on a conceptual level, howsoever controversial the concrete legal implementation could prove. ${ }^{69}$

Krause hereby provides an interesting, indeed provocative contribution to globalization ethics, seeking to mediate between theoreticians who claim that no possession of rights is ever of permanent validity until the highest possible system of law is established on earth and those who claim that every historically acquired right must be binding for all times. "In between these, decisively emerges the unpartisan truth that subor-

\footnotetext{
${ }^{61}$ Krause, Lebenlehre oder Philosophie der Geschichte zur Begründung der Lebenkunstwissenschaft, 1904, 203 f.; see Fricker, Das Problem des Völkerrechts, Zeitschrift für die gesamte Staatswissenschaft 28 (1872), 91- 144.

${ }^{62}$ Krause, Das System der Rechtsphilosophie - Vorlesungen für Gebildete aus allen Ständen, 1874, $464 \mathrm{ff}$.

${ }^{63}$ Ibid., 467.

${ }^{64}$ Ibid., $449 \mathrm{f}$.

${ }^{65}$ Krause, Lebenlehre oder Philosophie der Geschichte zur Begründung der Lebenkunstwissenschaft, 1904, 204.

${ }^{66}$ Krause, Das System der Rechtsphilosophie - Vorlesungen für Gebildete aus allen Ständen, 1874, 348.

${ }^{67}$ Krause, Das Urbild der Menschheit, $2^{\text {nd }}$ ed., 1851, 147.

${ }^{68}$ Krause, Das System der Rechtsphilosophie - Vorlesungen für Gebildete aus allen Ständen, 1874, 463.

${ }^{69}$ Ibid., 466.
} 
dinate rights of subordinate legal persons have the authority to prevail" wherever they need not be "demoted by the novel higher ground of law into an inferior position, and [adjusted] accordingly to the now arising and emerging higher organism of rights", ${ }^{70}$

This need not always entail a transformation of historically acquired legal positions. There will always exist particular areas of life where individual "independence must be maintained" ${ }^{71}$ The accession of a state to a community of peoples will leave many of its local structures - say, most regulations concerning family life - unchanged. But, in respect especially to geographical assets, a compensation in favor of disadvantaged peoples must be expected. As the actual occupation of nature and its treasures has taken place as a result of power-relations, it often ran counter to the "authority to take possession of the earth" ${ }^{\text {"72 }}$ which, normatively, belongs to all human beings equally. For that reason, the first possession of land is unlikely also to be the last. ${ }^{73}$

Such a fairness-oriented transformation of global ownership presupposes the "insight" and "good, rightful will"74 of the global citizens, which is obviously not always a given. Instead, quite often, where questions of redistributive justice are at stake, there prevails violence between individuals as well as peoples. ${ }^{75}$ Krause nevertheless believes that hope for a growing legal penetration of such areas of conflict is justified. Advancing civilization plus a sense of justice, on the one hand, and people's prudent self-interest on the other, would make for significant driving forces for the global advance of law. ${ }^{76}$ Long-term economic calculations of utility hand in hand with an appeal to "the conscience of mankind" itself towards the integrative regulation and protection of rights by means of global institutions. And, Krause adds, once a global order maintaining the interests and rights of all of earth's citizens arises, it would also - because of the economic advantages attained through membership - be very likely to endure. ${ }^{78}$

Krause in no way wishes to level the diversity of civilizations in that envisioned global federation of law, but rather especially aims to protect cultural diversity through the progress of cosmopolitan law. ${ }^{79}$ While, in a legally unregulated world, the economic and military powers of the day can raze traditional cultures as they please, weaker civilization have much better chances for the preservation of their lifestyles in well-ordered bodies of cosmopolitan law. In other words, precisely because, for Krause, the earth belongs to all people and peoples for the realization of their individual freedom, the lifestyles of cultures may also manifest themselves in dissimilar ways of life. The basic right of all humans to a self-determined life may well lead to a multiplicity of divergent

${ }^{70}$ Ibid., 328.

${ }^{71}$ Krause, Vorlesungen über Naturrecht oder Philosophie des Rechts und des Staates, 1892, 264.

${ }^{72}$ Ibid., 262.

73 Ibid.

${ }^{74}$ Ibid., 264.

${ }^{75}$ Ibid., 265.

${ }^{76}$ Ibid., 268.

${ }^{77}$ Krause, Das Urbild der Menschheit, $2^{\text {nd }}$ ed., 1851, 305.

${ }^{78}$ See Vester, Sozialphilosophie und Sozialpolitik, der deutschen Rechtsphilosophie des XIX. Jahrhunderts (Krause, Ahrens und Röder), 1935, 11; as well as Wollgast, Karl Christian Friedrich Krause (1781-1832): Bemerkungen zu seinem Menschheitsbund und Friedensplan, in: Lange (ed.), Philosophie und Frieden: Beiträge zum Friedensgedanke in der deutschen Klassik, 1985, 260-276.

${ }^{79}$ See MacCauley, Karl Christian Friedrich Krause: Heroic Pioneer for Thought and Life, 1925. 
local and regional legal systems. These can continue to exist as, in essence, internal specifications of a globally networked system of rights and freedoms. ${ }^{80}$

\begin{abstract}
"That implies that neither is justified the one claim which in recent times was fanatically claimed and striven for: that all men could have absolutely only identical equal rights. Nor is justified the other claim, which was just as fanatically taken up and enforced: that every man could have only his own quite individual right, and consequently one is unable to think about a universal (human) right possessed by all men. Both of these erroneous claims rather rest upon two basic truths, which were however at the same time misunderstood and comprehended in a one-sidedly exaggerated fashion. The universal, ever equal right of man is the eternal, unchangeable, and forever remaining foundation, but, on this foundation, rights must then be further determined." ${ }^{81}$
\end{abstract}

This theorem has tangible practical consequences. While, at the beginning of the nineteenth century, most German philosophers inferred from the de facto marginalized role of colonized peoples an inferior status for them in terms of rights and political freedom, Krause boldly marches in the opposite direction. The "One indivisible human nature" 82 which all individuals share in must be respected vis-à-vis all persons regardless of where and how they live. Not only does Krause strongly reject all racial differentiations within the right to freedom. He also strongly disapproves of the reference to a supposed cultural gap between European and non-European peoples, common at the time for the justification of colonialism. Back then, Krause was already using arguments very similar to those used by social justice advocates today: ${ }^{83}$ Those differences of cultivation and civilization, Krause holds, largely do not at all exist in the intensity claimed. But where they do exist, they have in many cases first been brought about by colonial practices in violation of international law. Therefore, cultural and socio-economic differences may never be employed for the justification of political subordination, as legal grounds for (further) discrimination, or as proof of racial inferiority. Those asymmetries rather obligate the world citizenry to support with solidarity those affected as well as to provide remediation for the past injustices of colonialism. ${ }^{84}$

\title{
VI. Conclusions
}

Krause's cosmopolitan vision is astonishing. Two hundred years ago, far ahead of the general trend in the social sciences of his era, he already shows the sociological as well as normative boundaries of the nation-state and takes up the theme of globalization. Moreover, instead of decreeing his vision for a global order 'from above,' Krause fends for a cosmopolitan ethics whose specifications derive from the voice and participation

\footnotetext{
${ }^{80}$ Krause, Das System der Rechtsphilosophie - Vorlesungen für Gebildete aus allen Ständen, 1874, $539 \mathrm{f}$.

${ }^{81}$ Krause, Lebenlehre oder Philosophie der Geschichte zur Begründung der Lebenkunstwissenschaft, 1904, 197.

${ }^{82}$ Krause, Das System der Rechtsphilosophie - Vorlesungen für Gebildete aus allen Ständen, 1874, 469.

${ }^{83}$ See Pogge, World Poverty and Human Rights: Cosmopolitan Responsibilities and Reforms, 2002.

${ }^{84}$ Krause, Das System der Rechtsphilosophie - Vorlesungen für Gebildete aus allen Ständen, 1874, 464.
} 
of precisely those global citizens for whom it wishes to provide orientation on the path towards an ever-closer legal and political integration of the world.

Certainly, Krause did not believe that philosophical ideas alone could change the world, but he also never gave in to the opposing view that the world could manage just fine without them. Human beings are, not in the least, what they become; and the latter results in part from what they strive for. Only a theory which takes seriously the normative ideals of humanity is thus of true practical value. And to such a realistic idealism Karl Christian Friedrich Krause devoted his cosmopolitan agenda.

Claus Dierksmeier,

Eberhard-Karls-Universität Tübingen,

E-Mail: claus.dierksmeier@uni-tuebingen.de 